\title{
Social inequality and human development: Intertwined cycles of perversion in education in contemporary Brazil
}

\author{
Desigualdad social y desarrollo humano: ciclos de perversion \\ entrelazados en educación en el Brasil comtemporáneo
}

L'inégalité sociale et le développement humain : les cycles entrelacés de perversion de l'éducation au Brésil contemporain

\author{
Naomar de Almeida Filho \\ Universidade Federal do Sul da Bahia, Brazil
}

\begin{abstract}
In this paper, a conceptual framework of the sources and origins of inequalities in education is presented, focusing on the Brazilian contemporary context as a case study of a paradox: reduced economic inequality in parallel to increasing inequities in education. To understand this apparent contradiction, first the Brazilian taxation structure is outlined as an intricate, regressive, and unfair system organized for collecting economic revenues for funding the State. Secondly, the social and political inequities that affect and thus define the educational structure of Brazil are discussed to reveal the perverse effects that turn education into a major asset for the general reproduction of society. Finally, such paradoxes and contradictions in the field of education are analyzed as strategies for maintenance and reproduction of a social order based on social inequalities and inequities.
\end{abstract}

Key words: education, inequality, social exclusion, social reproduction, Brazil.

\section{RESUMEN}

En este trabajo, se presenta un marco conceptual sobre fuentes y orígenes de las desigualdades en la educación, centrándose en el contexto contemporáneo de Brasil como un estudio de caso de una paradoja: se ha reducido la desigualdad económica en paralelo con el aumento de las iniquidades en educación. Para entender esta aparente contradicción, primero la estructura impositiva de Brasil se perfila como un sistema complejo, regresivo e injusto de recogida de los ingresos económicos para la financiación del Estado. En segundo lugar, las desigualdades sociales y políticas que afectan y por lo tanto definen la estructura educativa de Brasil se discuten para revelar los efectos perversos que convierten la 
educación en un activo importante para la reproducción general de la sociedad. Por último, tales paradojas y contradicciones en el campo de la educación se analizan como estrategias para la conservación y la reproducción de un orden social basado en desigualdades y iniquidades sociales.

Descriptores: Educación, desigualdad, exclusión social, reproducción social, Brasil.

\section{RESUME}

Dans cet article, un cadre conceptuel des sources et des origines de l'iniquité dans l'éducation est présenté en centrant sur le contexte Brésilien contemporain comme une étude de cas d'un paradoxe : la réduction de l'inégalité économique est mise en parallèle avec l'augmentation des iniquités en éducation. Pour comprendre cette contradiction apparente, en premier lieu la structure brésilienne est présentée dans ses grandes lignes comme un système compliqué, régressif et injuste organisé pour amasser des revenus économiques pour financer l'état. En second, les partages sociaux inéquitables qui affectent et définissent ainsi la structure éducative du Brésil révèlent des effets pervers faisant de l'éducation un atout majeur pour la reproduction de la société. Enfin, de tels paradoxes et contradictions sont analysés comme des stratégies pour conserver et reproduire un ordre social basé sur les inégalités et iniquités sociales.

Mots clés : éducation, inégalité, exclusion sociale, reproduction sociale, Brésil.

Several authors have pointed out the negative impact of economic and social inequality upon human development (Piketty, 2014; Stiglitz, Sen, \& Fitoussi, 2009). Evidence in this regard has subsidized proposals and recommendations for equity-oriented educational policies of national and international scope (ECLAC, 2014; UNDP, 2011; UNESCO, 2015; World Bank, 2004). In Latin America and the Caribbean, international and inter-regional disparities, inequalities by income groups, and social class gradients in levels of education have called the attention of researchers and government agencies (Barros et al., 2009; Battistón, García-Domenech, \& Gasparini, 2014; López-Calva \& Lustig, 2010).

In Brazil, knowledge gaps and biases in political and academic discourses have led to reduced effectiveness of social policies aimed at promoting equity in education (CDES, 2014). Despite governmental programs for expansion of educational opportunities and coverage at different levels of schooling, illiteracy remains a problem in the country, the performance of Brazilian students in international tests is not improving, and higher education is still restricted to select social groups (Brasil/MEC, 2015; CDES, 2014; UNESCO, 2015a).

To address such problems in a conceptually consistent, methodologically rigorous, and politically effective approach, a first step is to pursue critical conceptions of society capable of explaining the agents' practices in the social field of education (Bourdieu, 2012; Bourdieu \& Passeron, 2008). This conceptual demand can be satisfied by construction and 
validation of explanatory models, grounded on theories of fairness and justice. More specifically, to understand better the role of inequalities, it is imperative to address the question of which phenomena, states, processes, and events determine occurrence, characteristics, and performance of social gradients away from equality. Nobel Prize social economist Amartya Sen (1979) formulated this fundamental issue as a question: "Equality of what?"

A further methodological step is also necessary to produce critical knowledge on this topic. This step is to define the level of abstraction applied to the study of social relationships that integrate unequal education as both isolated and joint effects, taking into account educational deficits and academic achievement as much as professional competence, full citizenship, and quality of social life. In this regard, first, one must consider the population dimension, involving individual and collective levels, highlighting geopolitical amplitudes (municipality, state, country). Second, social dimensions - both micro (such as family or peer group) and macro (such as strata or social class) - must be considered. Third, symbolic-ideological dimensions are most important, recognizing cultural, ethnic, and racial differences (like subcultures or ethnic groups) as sources of distinction and of inequalities. For a clearer understanding of such a complex web of concepts and dimensions, integrated theoretical models of education are needed, based on the analysis of real contexts and situations (Oakes, 2005).

In this paper, I propose to elaborate (on a preliminary basis) on such a conceptual framework as applied to the Brazilian contemporary context, addressing the following key questions: What are the sources and origins of inequalities in education in our country? Where (in the sense of social and political space) and how (in the sense of societal and institutional processes) do social determinants of schooling and education operate? What are the mechanisms by which such inequalities articulate and interact? How do oppression and social injustice act in promoting the persistence of inequalities in education in contemporary Brazil?

\section{Current situation: Context and trends}

A former Portuguese colony whose economy was based on depletion of natural resources, genocide of native populations, and massive slavery, Brazil developed as a nation with a social structure founded on deep inequalities and on a political system defined by deficits in social justice (Fausto, 1999). Given the subsequent difficulties to establish itself as a democratic society along the $20^{\text {th }}$ century, the country still struggles with a huge political debt due to all sorts of inherited structural inequalities (Bresser-Pereira, 2014). This historical social debt is indeed the greatest challenge primarily faced by the reconstruction process of the Brazilian nation, after the military dictatorship that ended in 1985.

In recent years, Brazil has gone through a process of major economic, demographic, and social changes, which has been regarded as a new model of development (Barrientos \& Amann, 2014). Constrained by historical and structural determinants linked to economic development, the multicultural characteristics of Brazilian society, and the role of a State organized in the Republican period in early $20^{\text {th }}$ century, challenges and problems have been generated by choices and contexts in a capitalist social and economic formation, 
integrated into a globalized economy (World Bank, 2004). Facing these challenges, the country is going through a rapid, rich, and complex political process towards building a democratic and socially developed society. Seven axes of advanced elements can be identified as structuring the current Brazilian political and development model:

1. Macroeconomics for employment and work opportunities

2. Building of economic infrastructure, social and urban

3. A regionally articulated techno-productive structure

4. Social protection, with guarantee of civil rights

5. Environmental sustainability

6. Sovereign international insertion

7. Strengthening of the State, political institutions, and democracy

Despite the recent sharp reduction in GDP growth given the persistent global crisis context, economic development in Brazil has been sustained in the long run. The priority in mineral and agricultural production for export and the extreme technological dependence of the national industrial sector has been emphasized as drawbacks of the Brazilian model of development (Barrientos \& Amann, 2014). Although successful in sustaining high employment rates and increasing recovery of salary levels for almost a decade, the country has not resolved the dilemmas and problems associated with demands for productivity and competitiveness of the workforce. Nevertheless, the industrial and agricultural expansion, based on the formation of a big and voracious internal consumer market and the export of raw commodities, has produced environmental problems and challenges.

Undeniably, in recent decades the country has experienced a relatively sovereign foreign policy, avoiding automatic political alignments or submission to economic blocs (Alden \& Vieira, 2005). Regarding the current social context, in parallel or in consequence of a process of steady reduction of social inequalities due to a network of public programs for food security and social protection, in many ways the country has succeeded in turning economic growth into human development (Barros et al., 2010; Bresser-Pereira, 2009).

As in Graph 1, per capita average income in Brazil increased more than 20\% between 1992 and 2012, while the gross national product (GNP) more than doubled. The graph also shows a significant and sustained improvement of the Gini coefficient, especially after 2001. The total reduction of the Gini coefficient was $15 \%$, from 0.637 to 0.527 , although it is still one of the largest in the world. However, we should be cautious because this coefficient expresses the income distribution among formal employees, and therefore includes neither capital gains nor revenues acquired in the informal economy. Consequently, the coefficient indicates only the reduction of income inequality among workers, failing to reveal concentration of wealth among affluent social groups and foreign investors. 
Graph 1: Historical evolution of GDP per capita and Gini coefficient (Brazil, 1996-2013)

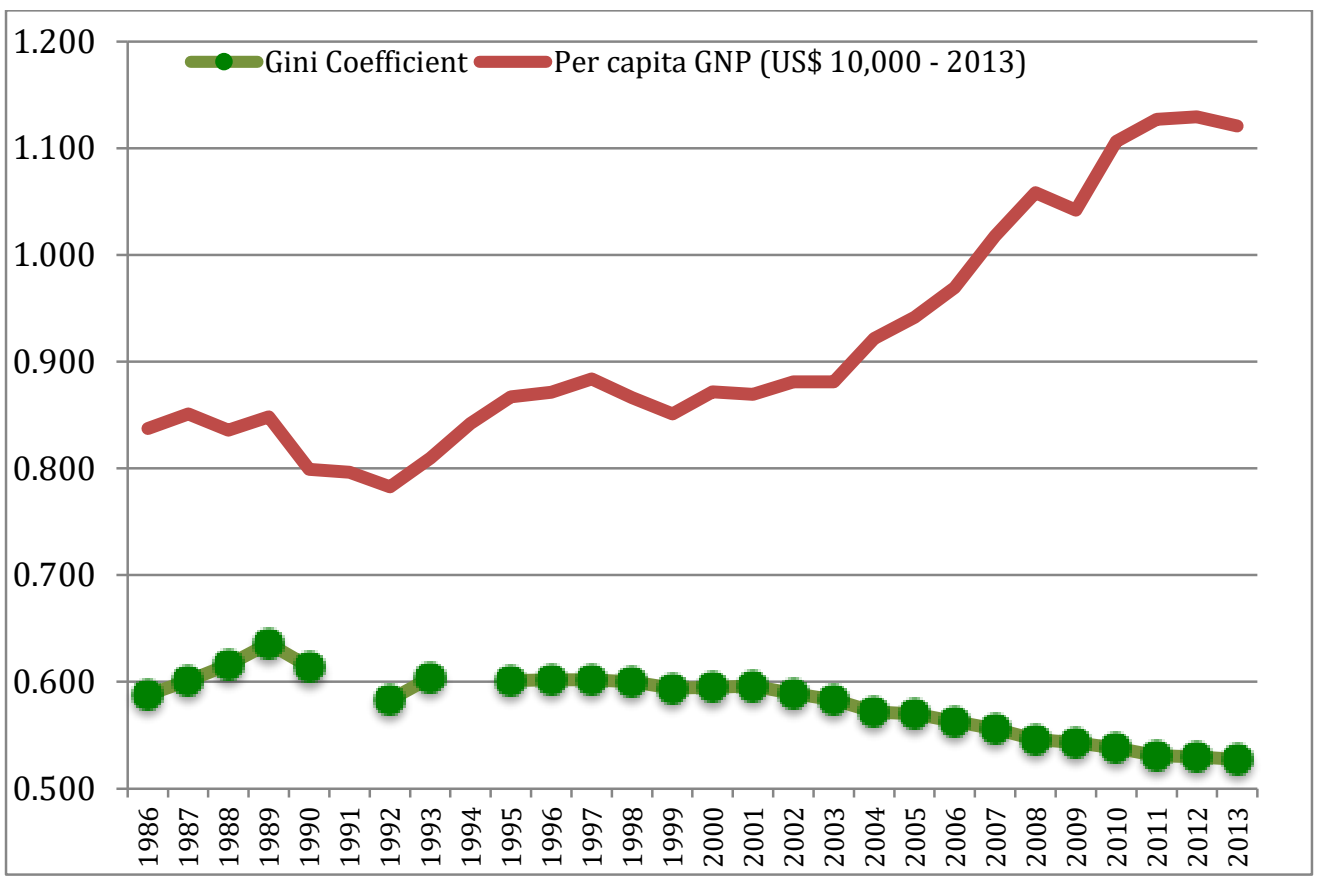

Source: IPEADATA, 2014.

The combined effect of economic growth and income redistribution - along with other processes such as rapid urbanization, more employment, and better schooling - has profoundly changed the social class structure defined as access to consumption markets (Barros et al., 2010; Ferreira, Firpo, \& Messina, 2014). Table 1 gives an overall view of the historical evolution of the country's social strata along two decades (1992 to 2012) as revealed in the proportional distribution of population segments classified by household monthly average income (Class A/B - income above US $\$ 3,000$; Class $\mathrm{C}$ - income between US $\$ 3,000$ and $\$ 700$; Class D/E - below US \$700), according to the best data available (IBGE Family Budget Survey). The growth in the proportion of middle and high income groups from $5.4 \%$ to $11 \%$ for the A/B segments and from $32 \%$ to $52 \%$ for the C group - was due clearly to upward social mobility for the poor and very poor D/E level, which reduced from $62 \%$ to $37 \%$. This phenomenon is what has been called, although arguably, the "new middle class" by some analysts.

The overall poverty rate decreased to $15.9 \%$ in 2012, with improvement attributed to social policies including the social security system and benefits of continued provision (BPC), the real increase in the minimum wage, and the national conditional cash transfer program called Bolsa Família (Ham, 2014; Wetzel, 2013). The latter program now reaches 14 million households and applies almost $0.5 \%$ of the country's GDP. Although the unemployment is relatively low, with rates below $8 \%$, over $40 \%$ of workers are still in the informal sector, which poses serious consequences for the stability of the social security system. In 2012, more than 95\% of homes had water supply and electricity, and $65 \%$ had access to sewage systems. In the past ten years, school attendance has increased, the illiteracy rate dropped to less than $10 \%$, and enrollment in higher education more than doubled. In 2012, the proportion of people over 60 years reached $13 \%$ of the population, 
the urbanization rate reached $80 \%$, the fertility rate dropped to 1.7 , and life expectancy at birth reached 75 years overall ( 71 years for men and 78 years for women). Infant mortality reduced markedly from above 30 deaths per thousand born alive in 1992 to 15.6 per thousand in 2012.

Table 1: Distribution of social groups classified by income, Brazil 1992-2012

\begin{tabular}{|l|l|l|l|}
\hline & Year & $\mathbf{2 0 0 2}(\mathbf{\% )}$ & $\mathbf{2 0 1 2}(\mathbf{\% )}$ \\
\hline Income groups & $\mathbf{1 9 9 2}(\mathbf{\% )}$ & 10 & 11 \\
\hline A/B & 5.4 & 10 & 52 \\
\hline C & 32.5 & 42 & 37 \\
\hline D/E & 62.1 & 48 & 100.0 \\
\hline Total & 100.0 & 100.0 & (2) \\
\hline
\end{tabular}

Source: FGV-CPS, 2014.

In this context - described as an outstanding model of economic growth fueled by the internal market combined with expanded social development (Barrientos \& Amann, 2014; Barros et al., 2010; Bresser-Pereira, 2009) - there seems to be a contradiction. On one hand, reduction of economic inequalities due to social protection policies of conditional cash transfer foster consumer participation of population segments excluded from a market economy for centuries (Ferreira, Leite, \& Litchfield, 2008). On the other hand, there is evidence that different sorts of social inequities are increasing, mainly due to a wider top-bottom gap of the quality, type, and reach of public services. The contradiction lies in the evidence of equity associated with inequity. That is, there is more equity in the economic sense, with undeniable improvement in patterns of income distribution among workers and consequently capacity of consumption, but paradoxically more inequity in the social aspects - on one hand enlarging the gaps in education and, on the other, maintaining the unequal concentration of social and political capital. Despite all the advances, recognized in general, there remain deep social inequities that deserve special attention, not only from all levels of government but from the whole society.

Economic equity producing social inequity seems to be indeed a disconcerting paradox. Trying to understand this paradox, I would like to propose a hypothesis: the State in Brazil has not complied with its responsibility to guarantee the population public services in amount and quality, with universal access and equity, as established in the 1988 Constitution. Even worse, in a subtle, discreet, and camouflaged fashion, the State has become a promoter of social inequities in the sense that some of its ongoing public policies end up producing perverse effects. This proposition may seem too simple and straightforward and, for this very reason, should be hard to understand and accept. Therefore, to make sense out of such a contradictory set of variables and vectors, we need conceptual tools fit to analyze the failure of the State in relation to public policy in contemporary Brazil.

In Figure 1, consider a simplified model of economic and social reproduction of political domination based on continuous processes of engendering inequality. In this model, an unfair regressive tax system, supported by a legal order and a political structure 
bound for social reproduction, leads to social perversion primarily in education (but also in other sectors such as health, housing, and public security), producing inequities in the educational system and therefore, inequalities in the social situation. The triple conjunction of perverse cycles, inter-articulated as dialectical processes, feeds back into the political system that conditions the State as an overwhelming and contradictory inequalityproducing institutional complex.

Figure 1: The dynamics of social reproduction of inequalities in contemporary Brazil

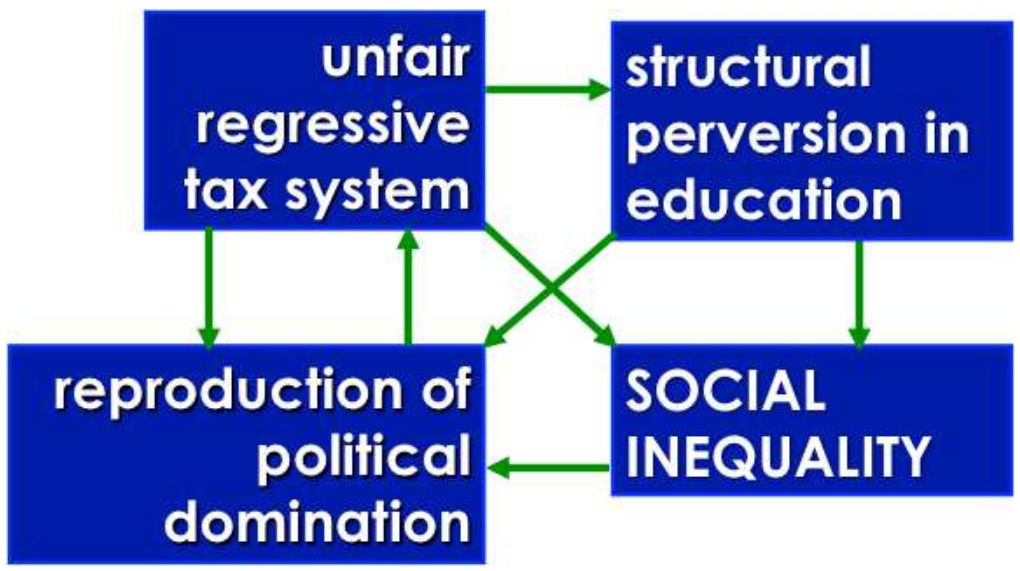

In the following sections, let me decompose this scheme. With this aim, first, I present briefly the Brazilian taxation structure, outlining its features as a deeply intricate, regressive, and unfair system organized for collecting economic revenues for funding the State. Secondly, in trying to reveal the perverse effects that turn education into a major asset for the general reproduction of society, I discuss the social and political inequities that affect and thus define the educational structure of Brazil. In this analysis, I attempt to identify paradoxes and contradictions that tend toward maintenance and reproduction of a social order based on social inequalities and inequities.

\section{The tax system of Brazil}

The media and private sector representatives persistently denounce that Brazil's tax burden is the highest worldwide, and growing. A consortium of commercial associations and consultation firms maintain a "tax-o-meter" in São Paulo's financial district that shows in real-time the increasing amount of tax collected at any given moment. ${ }^{1}$ Also, spokespersons of these organizations convey the idea that such an overload is somewhat evenly (or democratically) distributed across productive sectors and social groups.

However, empirical evidence shows a quite different picture. Analyses of comparative data have demonstrated that the Brazilian tax burden in general lies within the range of Western industrialized countries (CETAD, 2014; IBPT, 2013; Pintos-Payeras, 2010). Yet it has steadily increased, from around $22 \%$ of the GDP by the end of the military regime, to $30 \%$ in Fernando Henrique Cardoso's presidency, up to 34\% during Lula's presidency, and now around 37\% after Dilma Rousseff's. Brazil's 2012 gross tax load, 35.9\% of the GDP, is

\footnotetext{
${ }^{1}$ http://www.impostometro.com.br/
} 
the highest in Latin America (Paes, 2013), but it replicates almost precisely the OECD average and is much lower as compared to the average of Western countries with public social insurance and national health systems.

The country's taxation structure is indeed intricate, comprising almost a dozen taxes and compulsory contributions at municipal, state, and federal levels. A recent PwC/IFC/World Bank report (2014), a comparison of tax systems of 189 countries worldwide, ranks Brazil as the most time-consuming tax regime in the world, for its complexity and inconsistency. It is composed mainly of heavy indirect taxation on consumption goods and services, with income taxes (mostly on salaries and almost none on profits and rents) in the middle-range and a very small load of taxation on properties, fortunes, and inheritance. In Brazil, indirect taxes on products are $16.3 \%$ of GDP or $46.8 \%$ of the total tax burden, as compared to OECD average of $10.9 \%$ of GDP or $30.4 \%$ of the total burden. Taxes on income and revenues comprise $8.9 \%$ of GDP or $25.6 \%$ of the total tax burden in Brazil; the average OECD is $15.1 \%$ of GDP or $42.3 \%$ of the total burden. Inheritance or fortune taxes are absent at a national level; only Sao Paulo State collects 4\% of the wealth inherited as taxes, as compared to the average $41 \%$ of mature capitalist economies such as England, the United States, and Germany.

However, being time-consuming, complex, and obscure is not the major problem of Brazil's taxation regime. From a socio-political and ethical point of view, it is unequal, unfair, and profoundly unjust, being the paradigm of an extreme socially regressive system. Revenue taxation penalizes workers and those at the bottom of the income distribution. In addition, wealth is not taxed, and inheritances and donations are exempt from income taxes.

Indeed, according to official data consolidated by the Equity Observatory of the Council for Economic and Social Development (CDES, 2011), the system charges proportionally more to low-income taxpayers. Those who receive less than 2 minimum salaries (around US $\$ 300 /$ month) pay $49 \%$ of their wages in taxes, while those who earn more than 30 minimum wages (above US $\$ 9,000$ a month) pay only $26.3 \%$ in taxes out of their income. The maximum rate for revenue taxation in Brazil is $27.5 \%$, as compared to the OECD average of almost 45\%. Given numerous exemption clauses, the retention rate for higher-income taxpayers is only 13.8\%. Silveira et al. (2013), using IPEA data for $2008 / 2009$, report that the poorest $10 \%$ of the population pays $32 \%$ of their earnings in taxes, as compared to only $12 \%$ for the top tenth. These findings clearly demonstrate a strong negative correlation between income and tax payment. The poorest pay more taxes to fund a state that, in the ideal design of the Welfare State, should be a benefactor political body, an equity-building tool - but it is not.

The evidence that the Brazilian taxation regime actively promotes income concentration is of widespread recognition (CDES, 2011; IPEA, 2009; Paes, 2013; PintosPayeras, 2010) but, unfortunately, still restricted to analytical and academic spheres. These findings should be brought to a wider discussion in the social and political sphere. The most shocking conclusion of all is that the country's tax structure creates a reverse Robin Hood effect as a source of economic and social inequality, representing a perversion given 
the relative contribution of the poorest vis à vis the richest for the financial sustainability of the Brazilian State.

\section{Perversion in education}

Education is cited in the Brazilian Constitution as a citizen's right and a duty of the State. The public system of basic education in Brazil is theoretically universal, but - underfunded and with recognized deficiencies and imbalances - contributes to the increasing social exclusion of the poor (Corbucci et al., 2008). Indeed, in contemporary Brazil, two vicious cycles of reproduction of social inequalities operate through education, as shown in Figure 2.

Figure 2: Perverse effects in education in contemporary Brazil

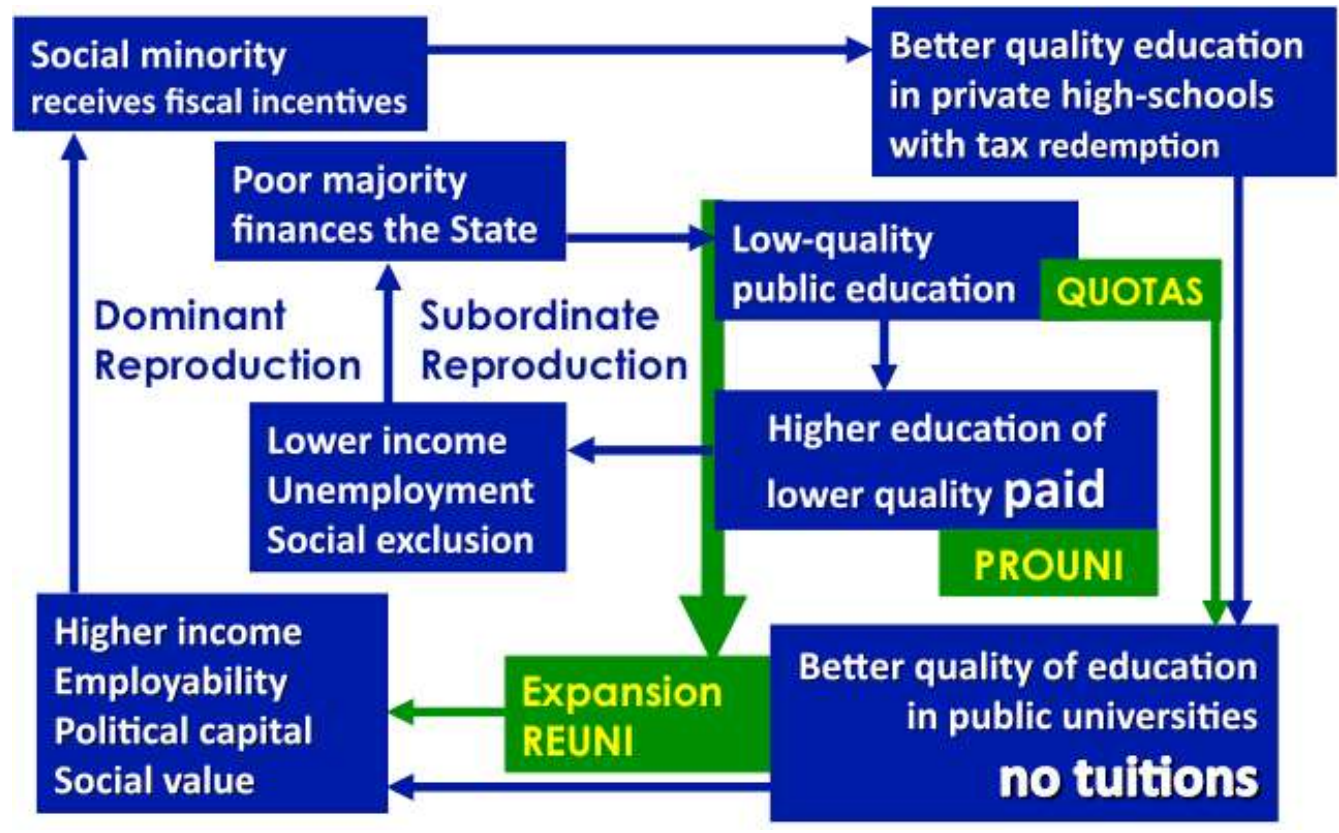

As discussed above, a social minority, economically privileged and politically dominant, receives tax exemptions, incentives, and benefits from state and federal governments, which paradoxically are funded by compulsory contributions mostly collected from the poor segments of the population. Middle and upper class families can afford to pay private secondary schools, in general of better quality, supported by a significant tax waiver, which benefits the individual taxpayer of higher income. In these schools, their children have quality basic education and are better trained to pass the selective filters, supposedly meritocratic, for entry into public universities. In addition, they benefit from family learning, the cultural capital accumulated through the acquisition of social skills and intellectual habitus - such as participation in discussions, readings, attendance to museums, cinemas, theaters, and consumption of cultural works (like books and records). These features provide an advantaged position in the competition for places in the best public universities, which are precisely those that offer better quality teaching for free. 
In contrast, young people from the poor majority that finances the state tend to go to a degraded public school system, unable to ensure their access to public higher education in federal or state universities. In the transition to higher education - crucial to define employability, social and economic inclusion, future assurance, and individual and collective projects - there is an inversion. For the poor and black youth who received lower quality public education but still, overcoming all sorts of obstacles, managed to complete this phase of their education, the only option left is higher education of lower quality - and paid. Limited to private higher education of poor quality, these young graduates face lower income, unemployment, and social exclusion, which closes this first cycle of social perversion. This pattern implies a deep, absolute injustice.

This cycle is dominated by the larger cycle of reproduction of social inequalities through education, because the best quality public higher education is free for the rich, because constitutionally the state is not allowed to charge them. On the contrary, there are tax incentives for non-poor young people to have their training refunded by the state, and thus accumulate more cultural capital, beyond that legacy. In addition, attending a public university strengthens social bonds with other agents coming from the elites, which consolidates the inherited social capital and expands the ability to enter the labor market and economic capital accumulation. And so the cycle is closed, because the reproduction of social inequality is complete when these young people will make up the new generation of the ruling minority that, by controlling companies and governments, reproduce relations of domination.

In sum, to understand the dynamics that somehow organize the set of social vectors in the education domain, I propose to consider "the four perversions of education" in Brazil:

1. The poor segments of society finance, to a disproportionately greater extent, the Brazilian State, through a distorted and regressive tax structure.

2. Those who are poorer receive little benefits from the State, among them, the constitutional duty of providing Basic Education for all citizens. The Brazilian state instead subsidizes, by revenue tax reimbursement, wealthier families that are potentially able to mobilize resources to account for this stage of education for their children.

3. The poor have to pay for higher education in the private sector institutions while the rich, instead, go to the best universities, which in general are public and charge no tuition or fees.

4. Then, there is a fourth perversion, which focuses on how the state interferes with the effects of education after graduation and at the post-graduate level. Advanced professional or academic education is a key factor in determining higher wages and greater access to management and leadership positions, either in the public or in the private sector, to an extent yet unexplored in the specialized scientific literature. In Brazil, the best Masters and doctoral programs are free, offered by public universities, subsidized by State and Federal governments, with extensive scholarships program and financial support for graduate schools. 
As stated elsewhere, in my judgment, the third perversion is the most serious from the point of view of equity in the public education policy (Almeida-Filho, 2012). In addition to having priority access to free public higher education, if by chance rich families have to pay for a private college for one of their children, they will also benefit from income tax refunds from the time their students are in university up to the legal limit of 24 years of age. As the Brazilian career training structure is short and starts very early (for instance, entry into medical or law courses at the age of 17 and graduation around 21 or 22 years is not uncommon), unlike other countries in the world, here upper and middle-class youngsters normally conclude their education before the age of 24, thus taking full profit from the socially unfair discounts in taxation. In opposition, lower class students, who tend to reach higher education later in life, take longer to graduate because, in general, in addition to studying, they have to work for survival. Therefore, their tuitions and fees are not reimbursable because they are above age limits for the tax rebate.

Along with affirmative action programs such as quotas for poor, black, and indigenous students, two focused governmental policies for higher education - called PROUNI and REUNI - have helped promote integration between the two cycles of reproduction. PROUNI (Programa Universidade para Todos) is a massive scholarship program launched in 2005 to finance university tuition at private higher education institutions for students from low-income families (Brasil/MEC, 2005). REUNI (Program for Restructuring and Expansion of Federal Universities) is a university reform initiative launched in 2007 for the expansion of federal universities (Brasil/MEC, 2007). These initiatives may be effective to reduce some of the negative consequences of the perversion cycles, restricted to a few beneficiaries, although they do not challenge exclusionary structural features of the Brazilian system of education (Almeida-Filho, 2012).

\section{The role of public policies in education}

As mentioned above, government focal policies were aimed at dealing with specific features of this perverse structure, without tackling its fundamental problems. Along with investments to expand public basic education, looking for quality and coverage, programs focusing on higher education would complement redistributive or compensation universal policies.

As far as higher education is concerned, the first wave of expansion, promoted in President Lula's two terms, between 2003 and 2010, was grounded on two programs: PROUNI and REUNI, as cited above. Primarily, new forms of selection process were implemented, based on the improvement of the National Secondary Education Examination (ENEM) to be used similarly to the SAT system in the US.

The PROUNI program was launched to allow students from low-income families to enter into paid higher education private institutions. It has two main features: a) private universities receive tax exemptions in exchange for providing full scholarships to regularly registered students; and b) those who have studied in public high schools receive full or partial scholarships paid by the Ministry of Education. Eligible students are those from 
families with a monthly income no greater than between one and a half and three minimum wages, classified according to performance in the ENEM.

In 2007, Brazil's Ministry of Education launched an ambitious university reform initiative with an accompanying 4-billion dollar investment plan called REUNI. The major axes of the REUNI reform were: a) expanded enrollment, with territorial and social inclusion; b) recovery of funding and investments for public universities; c) increase of teaching staff; d) new forms of selection process; e) restructuring curricula; and f) revision of post-graduate programs. Within the framework of REUNI, several universities in Brazil adopted the system of learning cycles, including interdisciplinary undergraduate courses compatible with the American university system and the Bologna model in Europe.

In parallel, with governmental induction and support, several Brazilian public universities started bottom-up affirmative action programs, using two major strategies quota systems, and bonuses for poor students and black/Indian minorities, leading to a legal approval of the Supreme Court in 2012. ${ }^{2}$ This policy eventually became a federal law, which establishes a quota of at least $50 \%$ of all available slots in federal universities for students coming from public schools, with an ethnicity factor within this quota matching that of the region in which the university is located. This is apparently a progressive step, but social inclusion as assimilation of outsiders promotes and sustains inequality in different contexts, eras, and places. More access for students from poor and subordinate ethnic groups to elite, conservative universities might become a successful cooptation practice. In the long run, this may reinforce the conservative core of the Brazilian university and surely will not help Brazilian society to overcome the reproductive cycles of inequality in education.

The Census of Higher Education (Brasil/MEC, 2014) has provided data to demonstrate this changing national picture. In 2002, less than $3 \%$ of the Brazilian population was enrolled in university. Since then, the crude enrolment rate has increased rapidly, mostly in public institutions: 120\% growth between 2002 and 2013. Lula's government (2003-2010) opened 14 new federal universities and 126 campuses of universities and technological training institutes. In 2011, President Dilma Rousseff announced a second expansion program, more focused although less ambitious than Lula's, with 4 new federal universities and 47 university campuses and technical school extensions implemented in cities identified as regional development poles, which have been chosen as targets for bulkier federal investments. In 2013, Brazil had a total of 195 universities, 89 public and 106 private. The public network - formed by 63 federal universities, 26 state universities, and 67 colleges and faculties - hosted 1.9 million students. The private sector consisted of 2,112 institutions, mostly small isolated schools, and held 5.1 million students. The system overall received 2.7 million new students (as compared to 1.4 million in 2002), $81 \%$ of them in the private sector.

As a result of continuing expansion and social inclusion policies, today $8 \%$ of the population has a university degree compared to $4.4 \%$ in 2000 . But the demand for higher education has soared because, during the past decade, more than 40 million people crossed

\footnotetext{
${ }^{2}$ http://www.stf.jus.br/portal/cms/verNoticiaDetalhe.asp?idConteudo=206042
} 
the poverty line and enrolment for elementary and secondary education doubled. Despite all efforts of governments and institutions, still less than 15\% of the 18-24 years agegroups are university students, which comprises only $3.4 \%$ of the Brazilian population, estimated above 200 million for 2015.

Beyond all quantitative achievements, if such policies do not have a counterpart on the tax system reform - becoming more progressive as well as reducing refunds and waivers for private education costs - the State will continue subsidizing the reproduction of inequalities in education, which promotes social inequities at all levels. Unfortunately, the impact of target programs and specific policies have not yet become widespread enough to make a difference regarding the magnitude of the social education debt inherited from the history of social segregation in Brazil.

\section{Conclusion: Articulated perverse cycles of social inequity}

In a sense, the inequity in higher education that concretely defines the current situation of Brazil is both qualitative than quantitative. In theory, all Brazilian citizens have access to all levels of education and, in fact, the country has almost guaranteed open access to the primary levels of elementary schooling. The question is who has access to which school - as some only have access to the same school system that discriminates and segregates citizens according to subtle signs of social power. The quality differential is revealed subjectively or insidiously, in the reception, in the student-teacher relationship, in the classroom, in the cheap low-quality supplies, and in the human quality of the education provided. It is related to or defined by stereotypes socially constructed, not to mention the stigma associated with social, ethnic, gender, and generation (Oakes, 2005).

Many such inequality factors are related to social origin (or cultural capital acquired and inherited) through the differential quality of education (Bourdieu \& Passeron, 2008). Other sets of variables include the information gap that prevents many people from accessing the best educational resources for lack of knowledge or mere ignorance; the social filter of having access to bureaucratic rings given political connections or family ties, friendship, and/or membership in a particular social group (social capital); the ideology of certain social classes and groups that overstates individualized education and personal life projects; and the low social value that the general public gives to the professorial personnel. Some of these elements are crucial for emphasizing the role of the higher education system as the major source of professional training of the workforce and of formation of participatory citizenship. Additionally, it is noteworthy that different positions in the social space or different social classes represent an important line of determination for the differential access to educational opportunities (Breen \& Jonsson, 2005).

The models and processes analyzed briefly here have started and spread in a context of neoliberal reform of the State (Bresser-Pereira, 2014). In this process, Brazilian civil society and the State have not yet overcome the public-private dichotomy inherited from the 1988 Constitution. At that point, official rhetoric about inter-sector governance indeed dissonant from the political reality, with programs rich in ideal targets and easy discourses but difficult to be carried out in concrete contexts - has proved to be instrumental in the conservation of models of public management, but not to overcome 
them. Admittedly, rationalizing, remedial, and compensatory social policies are growing, but this expansion is in my opinion too late and too limited. Overall, the structural changes of the Brazilian State (through true democratic reforms) have been delayed or jeopardized by retrograde political processes, with the real possibility of an ideological backlash. One can say that, along with the massive inclusion of social sectors previously excluded from the country's development, today there is in Brazil a political-ideological setback. Given this economic and political scenario, the window for expansion of public policies, dialectically related to the advancement of the struggle for structural transformation of Brazilian democratic society, perhaps has come to a close.

This is a historical process in which the power field - the ruling classes plus the State - is continuously reproduced in contemporary Brazil, aided by the expansion of higher education policies without transforming the elite university system. Also, the perverse structure of elementary and secondary education, which should constitute a factor of social inclusion and human development - as a duty of the democratic State, minimally because education, health, and social protection are rights for all - actually is reproducing social inequalities. Thus, in contemporary Brazilian social context, the reproduction of inequalities through a public policy supposedly aimed to reduce them is evident, as happened in France with the extension of compulsory schooling up to 16 years that, for this reason, universalized access to education secondary while keeping the reproduction effect of social inequalities (Bourdieu \& Passeron, 2008).

The issue is not only about government, but it is all about the State. If the production process of public policies is part of the State's role in relation to society, it is no less a responsibility of passing governments. Therefore, nobody can blame governments in order to charge responsibility, but to analyze the role of the State we would have to include an analytical dimension with explanatory potential from a particular theoretical framework. That is, the State intervenes historically in education (and other social sectors such as health) to contribute to the reproduction of the labor force, to reproduce the ideological matrices of society, and to alleviate social tensions between workers and the unemployed. In Gramsci's interpretation, this would depend on the historical hegemonic blocks and social classes that compose them, including disputes inside the proper apparatus of the State (Gramsci, 1989). And in Bourdieu's conception, the State is a political space where the dynamics of social fields and their disputes in relation to power operate and interact with a bureaucratic domain, which concretely constitutes the proper State (Bourdieu, 2012).

The crisis of the Brazilian educational system is therefore multifaceted: underfunded, suffering from bureaucratic and politically biased management, and unable to take the challenges of integrality, of social value, and of equity. In short, the Brazilian education system suffers from inequalities in funding, displays inequities in quality, and has experienced distortions in the models of management of resources and personnel. In this regard, the three vectors - tax system, society, and education - have been articulated for producing and promoting inequalities, inequities, and perverse effects. Budgetary increases for social programs, efficient management, transparence, participatory governance, affirmative policies, and a more effective fight against corruption and waste of public resources are potential strategies to overcome such a complex system of intertwined 
inequalities, provided that a broad political alliance might be apt to form an effective hegemonic bloc indeed committed to the human development of Brazilian society.

\section{References}

Alden, C., \& Vieira, V. (2005). The new diplomacy of the South: South Africa, Brazil, India and trilateralism. Third World Quarterly, 26(7), 1077-1095.

Almeida Filho, N. (2012). Breaking a vicious cycle of social exclusion: University education in contemporary Brazil. Revista: Harvard Review of Latin America (Fall), 60-63.

Barrientos, A., \& Amann, E. (2014). Is there a new Brazilian model of development? Main findings from the IRIBA research programme (Working Paper Series \#13). Manchester, England: Brooks World Poverty Institute.

Barros, R. P., Carvalho, M., Franco, S., \& Mendonça, R. (2010). Markets, the state and the dynamics of inequality in Brazil. In L. F. Lopez-Calva \& N. Lustig (Eds.), Declining inequality in Latin America: A decade of progress? Washington, DC: Brookings Institution and UNDP.

Barros, R. P., Ferreira, F. H., Molinas-Vega, J., \& Chanduvi, J. (2009). Measuring inequality of opportunity in Latin America and the Caribbean. New York, NY: Palgrave Macmillan; Washington, DC: World Bank.

Battistón, D, García-Domench C., \& Gasparini, L. (2014). Could an increase in education raise income inequality? Evidence for Latin America. Latin American Journal of Economics, 51(1), 1-39.

Bourdieu, P., \& Passeron, J. C. (2008 [1970]). A reprodução: Elementos para uma teoria do ensino. Petropolis, Brazil: Editora Vozes.

Bourdieu, P. (2012). Sur l'État: Cours au Collège de France (1989-1992). Paris, France: Seuil.

Brasil/MEC. (2006). Programa universidade para todos (PROUNI). http://prouniportal.mec.gov.br/o-programa

Brasil/MEC. (2007). Programa de reestruturação e expansão das universidades federais [Program for restructuring and expansion of federal universities] (REUNI). http://reuni.mec.gov.br/

Brasil/MEC. (2014). Censo da educação superior 2013. Brasília, Brazil: INEP/MEC. http://download.inep.gov.br/educacao_superior/censo_superior/apresentacao/20 14/coletiva_censo_superior_2013.pdf

Brasil/MEC. (2015). Education for All: 2015 national review. Brasília, Brazil: Ministry of Education.

http://www.acaoeducativa.org.br/desenvolvimento/wpcontent/uploads/2014/11/Informe_Brasil.pdf

Breen, R., \& Jonsson, J. (2005) Inequality of opportunity in comparative perspective: Recent research on educational attainment and social mobility. Annual Review of Sociology, 31(1), 223-243.

Bresser-Pereira, L. C. (2009). Developing Brazil: Overcoming the failure of the Washington consensus. Boulder, CO: Lynne Rienner Publishers. 
Bresser-Pereira, L. C. (2014). A construção política do Brasil: Sociedade, economia e estado desde a independência. São Paulo, Brazil: Editora 34.

CDES (Conselho de Desenvolvimento Econônomico e Social). (2011). Indicadores de equidade do Sistema Tributário Nacional. Observatório da Equidade - Relatório de Observação, n. 1. Brasília, Brazil: Presidência da República.

CDES (Conselho de Desenvolvimento Econônomico e Social). (2014). As Desigualdades na Escolarização no Brasil. Observatório da Equidade - Relatório de Observação no 5. Brasília, Brazil: Presidência da República.

CETAD (2014). Carga Tributária no Brasil 2013. Análise por Tributos e Bases de Incidências. Brasília, Brazil: Ministério da Fazenda - Centro de Estudos Tributários e Aduaneiros.

Corbucci, P., Barreto A., Castro J., Chaves J., \& Codes, A. L. (2008). Vinte anos da Constituição federal de 1988: Avanços e desafios na educação brasileira. In IPEA, Políticas sociais: Acompanhamento e análise, vol. 2 (pp. 17-76). Brasília, Brazil: IPEA/SAE.

ECLAC. (2014). Social panorama of Latin America. Santiago, Chile: United Nations Economic Commission for Latin America and the Caribbean.

Fausto, B. (1999). A concise history of Brazil. Cambridge, England: Cambridge University Press.

Ferreira, F. H. G., Firpo, S. P., \& Messina, J. (2014). Explaining the decline in earnings inequality in Brazil, 1995-2012 (IRIBA Working Paper \#12). http://dx.doi.org/10.2139/ssrn.2497969

Ferreira, F., Leite, P. G., \& Litchfield, J. (2008). The rise and fall of Brazilian inequality: 1981-2004. Macroeconomic Dynamics, 12(S2), 199-230.

FGV. (2014). A nova classe média. Rio, Brazil: Fundação Getúlio Vargas/Centro de Políticas Sociais. http://www.cps.fgv.br/cps/classe_media/

Gramsci, A. (1989). Maquiavel, a política e o estado moderno. Rio, Brazil: Civilização Brasileira.

Ham, A. (2014). The impact of conditional cash transfer on educational inequality of opportunity. Latin American Research Review, 49(3), 153-175.

IBGE. (2014). Síntese de Indicadores Sociais - Uma análise das condições de vida da população brasileira. Rio de Janeiro, Brazil: Instituto Brasileiro de Geografia e Estatística (IBGE)/Diretoria de Pesquisas - Coordenação de População e Indicadores Sociais, Estudos e Pesquisas. Informação Demográfica e Socioeconômica número 34.

IBPT. (2013). Evolução da carga tributária brasileira e previsão para 2013. Rio, Brazil: Instituto Brasileiro de Planejamento e Tributação.

IPEA (Instituto de Pesquisas Econômicas Aplicadas). (2009). Receita pública: Quem pagae como se gasta no Brasil (Relatório \#22). Brasília, Brazil: IPEA.

IPEADATA. (2014). Pesquisa nacional por amostra de domicílios (PNAD/IBGE). Brasília, Brazil: IPEA. http://www.ipeadata.gov.br

López-Calva, L. F., \& Lustig, N. (Eds.). (2010). Declining inequality in Latin America: A decade of progress? Washington, DC: Brookings Institution Press.

Oakes, J. (2005). Keeping track: How schools structure inequality. New Haven, CT: Yale University Press. 
Paes, N. (2013). Uma análise comparada do sistema tributário brasileiro em relação à América Latina. Acta Scientiarum: Human \& Social Sciences, 35(1), 85-95. periodicos.uem.br/ojs/index.php/ActaSciHumanSocSci/article/.../pdf

Piketty, T. (2014). Capital in the twenty-first century. Cambridge, MA: Belknap Press.

Pintos-Payeras, J. A. (2010, August). Análise da progressividade da carga tributária sobre a população brasileira. Pesquisa e Planejamento Econômico, 40(2), 153-186.

UNDP. (2012). Human Development Report - 2011. New York, NY: United Nations Development Program.

http://hdr.undp.org/en/reports/global/hdr2011/download/pt/

Sen, A. (1979, May 22). Equality of what? The Tanner Lecture on human values. Lecture delivered at Stanford University. http://tannerlectures.utah.edu/_documents/a-toz/s/sen80.pdf

Silveira, F., Rezende, F., Afonso, J., \& Ferreira, J. (2013). Fiscal equity: Distributional impacts of taxation and social spending in Brazil (Working Paper \#115). Brasília, Brazil: Brookings Institution Press - International Policy Centre for Inclusive Growth (IPCIG).

Stiglitz, J. E., Sen, A., \& Fitoussi, J. (2009, September 14). Report by the Commission on the Measurement of Economic Performance and Social Progress. Paris, France. http://www.stiglitz-sen-fitoussi.fr/documents/rapport_anglais.pdf

UNESCO. (2015). Education 2030: Equity and quality with a lifelong learning perspective (Policy Paper \#20). http://unesdoc.unesco.org/images/0023/002330/233029e.pdf UNESCO. (2015a). The Education for All global monitoring report. Paris, France: UNESCO. http://unesdoc.unesco.org/images/0023/002325/232565e.pdf

Wetzel, D. (2013). El programa Bolsa Familia y la revolución silenciosa en Brasil. https://www.wwp.org.br/es/articulo-deborah-wetzel-el-programa-bolsa-familia-yla-revolucion-silenciosa-en-brasil

World Bank (2014). Paying taxes 2014: The global picture. Washington, DC: PwC/IFC/World Bank. http://www.pwc.com/gx/en/paying-taxes/assets/pwcpaying-taxes-2014.pdf

World Bank. (2004). Inequality and economic development in Brazil. Washington, DC: World Bank. https://openknowledge.worldbank.org/handle/10986/14913 